\title{
Effect of black tea in diethylnitrosamine-induced esophageal carcinogenesis in mice ${ }^{1}$
}

\author{
Efeito do chá preto sobre a carcinogênese esofágica induzida por dietilnitrosamina em \\ camundongos
}

\author{
Átila Varela VelhoI, Antonio Atalíbio Hartmann", Cleber Dario Pinto Kruel ${ }^{\mathrm{III}}$ \\ ${ }^{\mathrm{I}} \mathrm{PhD}$ in Surgery, Assistant Professor, Surgery Department, UFCSPA, Brazil. \\ ${ }^{\text {II }} \mathrm{PhD}$ in Pathology, Associate Professor, Pathology Department, UFCSPA, Brazil. \\ ${ }^{\text {III }} \mathrm{PhD}$ in Surgery, Assistant Professor, Surgery Department, UFRGS, Brazil.
}

\begin{abstract}
Purpose: To evaluate the effect of black tea on esophageal carcinogenesis induced by the oral administration of diethylnitrosamine (DEN). Methods: A population of 120 female mice (Mus musculus, strain CF1) were studied for 160 days. The animals were assigned to two control groups and three treatment groups. The control groups received water or tea throughout the study period, while the three experimental groups received DEN weekly, for three consecutive days, and water, tea, or both, in the other days of the week. On completion of the 160-day period, the animals were killed and their esophagi promptly examined macroscopically and subsequently submitted to histopathology (using the hematoxylin-eosin technique). Results: In the comparative analysis between the treatment groups, tumor incidence (macroscopy) was significantly lower in those animals that received black tea besides the carcinogen. As regards the histopathologic changes, there was a greater number of low grade epithelial lesions in the same groups $(\mathrm{p}<0.001)$. Conclusion: The animals that received black tea had a lower incidence of effects related to the carcinogen's action, thus indicating that, in this model, the infusion had a significant chemoprophylactic effect on experimental diethylnitrosamineinduced carcinogenesis.
\end{abstract}

Key words: Esophageal Neoplasms. Tea. Chemoprevention. Diethylnitrosamine. Mice.

\section{RESUMO}

Objetivo: Avaliar o efeito do chá preto sobre a carcinogênese esofágica experimental induzida pela administração oral de dietilnitrosamina (DEN). Métodos: Durante 160 dias foi estudada uma população de 120 camundongos fêmeas, gênero Mus musculus, da cepa CF1, dividida em dois grupos controles e três grupos de tratamento. Os grupos controles receberam água ou chá durante todo o período do estudo. Os três grupos tratados receberam DEN semanalmente, durante três dias consecutivos, e água, chá ou ambos, nos demais dias da semana. Ao completar o período de 160 dias foram efetuadas as eutanásias dos animais e seus esôfagos foram analisados macroscopicamente (a fresco) e, posteriormente, à histopatologia (empregando a técnica da hematoxilina e eosina - HE). Resultados: Na análise comparativa entre os grupos de tratamento, a incidência tumoral (macroscopia) foi significativamente menor naqueles animais que receberam chá preto, além do carcinógeno. No que se refere às alterações histopatológicas, houve maior número de lesões epiteliais de baixo grau nesses mesmos grupos (p < 0,001). Conclusão: Os animais que receberam chá preto apresentaram menor incidência dos efeitos relacionados à ação do carcinógeno, indicando que, neste modelo, a infusão apresentou efeito quimioprofilático significativo sobre a carcinogênese experimental induzida pela dietilnitrosamina.

Descritores: Neoplasias Esofágicas. Chá. Quimioprevenção. Dietilnitrosamina. Camundongos.

${ }^{1}$ Research performed at Post-Graduate Program of Pathology, Federal University of Health Sciences of Porto Alegre (UFCSPA) and PostGraduate Program of Surgery, Federal University of Rio Grande do Sul (UFRGS), Porto Alegre, Brazil. 


\section{Introduction}

The current scientific stage $\mathrm{e}^{1,2,3}$ leads the theories of esophageal carcinogenesis towards the thesis of genetic origin, related to successive DNA transformations ${ }^{4}$.

Although esophageal cancer occurs universally, in certain eastern regions it represents a scourge ${ }^{5}$, as in these areas it is easy to evidence the connection between the disorder and local habits acting as risk factors ${ }^{2,6}$. Peoples of the northeastern Iran, the Kashmir Valley in India, northern China, and certain southern countries of the ex-USSR, owing to their unique feeding patterns ${ }^{7,8}$, and Asian and African peoples, owing to severe malnutrition, have a high incidence of esophageal cancer, constituting a living history of the genesis of the disorder in these regions.

Brazil is the fifth leading country in deaths by esophageal neoplasia, and the state of Rio Grande do Sul shows the highest incidence of the disease $\left(26: 10^{4}\right.$ people/year), which is also related to local habits such as eating barbecue and drinking chimarrão.

Other carcinogenic factors are related to the feeding habits, exerting a direct action on the esophageal mucous membrane or inhibiting the action of protective factors, such as the case of hot beverages, certain herbs, and N-nitrous compounds ${ }^{7}$.

Modern strategies of action against cancer are focused on the prevention of precursor alterations at cell level, seeking to inhibit mutations or reverse the incipient process of the disorder at one or more of the stages of carcinogenesis ${ }^{9,10,11,12,13}$. The ideal agent for this purpose must be not only effective but also natural, accessible, stable, nontoxic, well-absorbed by oral route, well-tolerated, of low cost, as well as having a known mechanism of action ${ }^{14}$. These inhibitors include the polyphenols, chemically active substances responsible for the anticarcinogenic efficacy of tea in experimental and epidemiological studies ${ }^{15}$. At locations where tea is abundantly consumed, at a temperature below $55^{\circ} \mathrm{C}$, a significant reduction in the cases of esophageal cancer is observed, suggesting an inhibitory action concerning this type of tumor.

This action of tea polyphenols appears to be related to several pharmacological effects, namely, antioxidant activity ${ }^{16}$, clearing of active radicals ${ }^{14,17}$, inhibition of enzymes participating in the carcinogenic metabolism ${ }^{18}$, increment of enzymes that catalyze inhibitory actions of the carcinogenic activity ${ }^{19}$, inhibition of the formation of the final carcinogen, and inhibition of the binding of the active carcinogen to the DNA, preventing its methylation ${ }^{20}$.

Although black tea accounts for $80 \%$ of the world consumption of tea, studies related to it are scarce. Research on the pharmacological effects of these infusions are more valued in the East, where the consumption of green tea predominates. Anyway, differently from previous research, recent studies in human volunteers suggest that black tea presents a anticarcinogenic effect in vivo which matches that of green tea, since the condensation undergone by its polyphenols during fermentation can be reversed under the action of the low gastric $\mathrm{pH}$ and metabolism ${ }^{21}$.

In this study we have investigated the effect of black tea on experimental esophageal carcinogenesis induced by oral administration of diethylnitrosamine (DEN) to a sample of female Mus musculus mice, strain CF1.

The work was carried out in three stages: in the first, two control groups were randomly created, which received tea or water, and three treatment groups submitted to tumor induction by DEN (Rubio's method), two of which received black tea in their diet, while the third did not receive the tea; the second stage consisted in a macroscopic assessment of the animals' esophagi, recording the number of tumors $\geq 1 \mathrm{~mm}$, and the histopathologic examination of these tumors and the other pieces; lastly, a comparative analysis between the groups was carried out in order to determine the degree of the influence of black tea on the chemical carcinogenesis in this experimental model.

\section{Methods}

The protocol used was approved by the Ethical Board for Animal Research of the Postgraduate Program in Surgery of UFRGS.

\section{Animals and experimentation setting}

120 female Mus musculus mice, strain CF1, were used. They were 60 days-old and had a mean weight of $31,37 \mathrm{~g}$ at the start of the experiment. The animals were maintained at controlled conditions in the experimental animals facility of the Fundação Estadual de Produção e Pesquisa em Saúde (FEPPS). For health management, the rats were electronically weighed at $60,90,120$ and 160 days. There were six deaths, which were not included in the data analysis.

\section{Phase 1 - Experimental chemical carcinogenesis}

The first phase of the study was the induction of esophageal carcinogenesis by oral route following RUBIO's method ${ }^{22}$. The carcinogen used was an aqueous solution of diethylnitrosamine - DEN (SIGMA CHEMICALS COMPANY - density $0.95 \mathrm{~g} / \mathrm{ml}$, molecular weight 102.1 and chemical formula $\mathrm{C}_{4} \mathrm{H}_{10}-\mathrm{N}_{2} \mathrm{O}$ ), at a concentration of $0.04 \mathrm{ml} / \mathrm{L}$ of water or black tea at $1 \%$, according to the group. The black tea - Camellia sinensis - (FLEISCHMANN \& ROYAL LTDA) was always used at a concentration of $10 \mathrm{~g} / \mathrm{L}$ of water (1\%). The solutions were given on an libitum basis and offered every week as follows: one of the control groups received only water and the other only black tea at $1 \%$ daily; experimental group I (DEN I) received water for 4 days and an aqueous solution of DEN for the rest of the week; experimental group II (DEN II) received black tea at $1 \%$ for 2 days, water on the next 2 days, and a solution of DEN in black tea on the remaining 3 days; experimental group III (DEN III) received black tea for 4 days and an aqueous solution of DEN on the other 3 days.

Phase 2 - Macroscopic and microscopic analyses

The mice were killed at 160 days $^{23}$ by inhalation of 
sulphur ether. Their esophagi were dissected out and then longitudinally sectioned throughout their extension and their measures were recorded. After a prompt assessment of the piece using a stereoscopic microscope (4x), the esophagus was fixed in a $10 \%$ formalin solution. It was previously decided that only tumors with masses greater than $\geq 1 \mathrm{~mm}$ would be considered, a determination that was done blindly.

Each tumor-containing esophageal section was transversally sectioned, with the care of maintaining a visual margin of normal tissue. It was then included in paraffin and transversal $2-\mu \mathrm{m}$ thick sections were obtained, then fixed and stained with hematoxylin-eosin (HE). The microscopic evaluation of the slides was performed blindly. The findings were classified in 4 types: normal; low grade dysplasia (increased cellularity without reaching the epithelial surface layer, frequent mitoses or discreet nuclear atypia); high grade dysplasia (pavement cells by the epithelial surface or at the basal lamina, without traversing it (carcinoma in situ), hyperchromatism or moderate nuclear atypia); and invasive carcinoma (severe cell disarray with intense nuclear atypia or pavement cells below the basal lamina).

Phase 3 - Data analysis

Data analysis was done taking as a basis all the tumors and esophageal specimens collected. Subsequently, a single pathological identity was ascribed to each animal according to the histopathologic lesion of highest grade presented.

The qualitative variables appear as absolute frequencies, and, as they involved ordinal variables, the median and minimum and maximum values were used as series descriptors. Using the Rank transformation, proposed by Montgomery, the comparison between groups was submitted to oneway ANOVA over Ranks, with localization of the differences by the DUNCAN post-hoc test. Box-plot graphs allow the visual evaluation of the differences found. The level of significance used was $p \leq 0.05$. The data were processed and analyzed using software SPSS V11.0 (Statistical Package For Social Sciences) and SigmaPlot V7.0.

\section{Results \\ General observations}

There were 6 early deaths, 2 from each treatment group, due to physical weakness secondary to the action of the carcinogen. The five groups presented a similar weight when they were first weighed, but over the experiment the control groups and DEN III showed a similar, positive weight variation, while group DEN I presented a negative weight variation, significantly different from the former. Group DEN II remained within an intermediate range of statistical similarity with these two blocks (Table 1).

TABLE 1 - Weight progress and tumor incidence across the groups

\begin{tabular}{lcccccc}
\hline \multirow{2}{*}{ Variable } & \multicolumn{7}{c}{ Groups * } & \begin{tabular}{c} 
P \\
\cline { 2 - 6 }
\end{tabular} & Water & Tea & DEN I & DEN II & DEN III & (ANOVA) \\
\hline Initial weight (g) & $31.70 \pm 1.44$ & $32.10 \pm 1.48$ & $31.28 \pm 1.44$ & $31.42 \pm 1.07$ & $31.25 \pm 1.32$ & 0.617 \\
Final weight (g) & $38.90^{\mathrm{b}} \pm 3.45$ & $39.00^{\mathrm{b}} \pm 1.73$ & $30.92^{\mathrm{a}} \pm 6.23$ & $32.96^{\mathrm{a}, \mathrm{b}} \pm 4.93$ & $36.02^{\mathrm{b}} \pm 2.16$ & $<0.0001$ \\
\hline $\begin{array}{l}\text { Mean number } \\
\text { of tumors }\end{array}$ & 0 & 0 & $2.25^{\mathrm{a}} \pm 1.40$ & $0.79^{\mathrm{b}} \pm 0.95$ & $1.06^{\mathrm{b}} \pm 1.01$ & $<0.0001$ \\
\hline
\end{tabular}

* The values appear as means \pm standard deviation.

The index letters represent statistically significant differences $(a \neq b)$.

\section{Macroscopy}

The mean number of tumors was significantly greater in group DEN I and similar across groups DEN II and DEN III (Figure 1). The control groups did not show tumors and their esophagi served as a standard of normality (Figure 2). There were no differences between the macroscopic characteristics of the tumors in the treatment groups (Figures 3 and 4). 


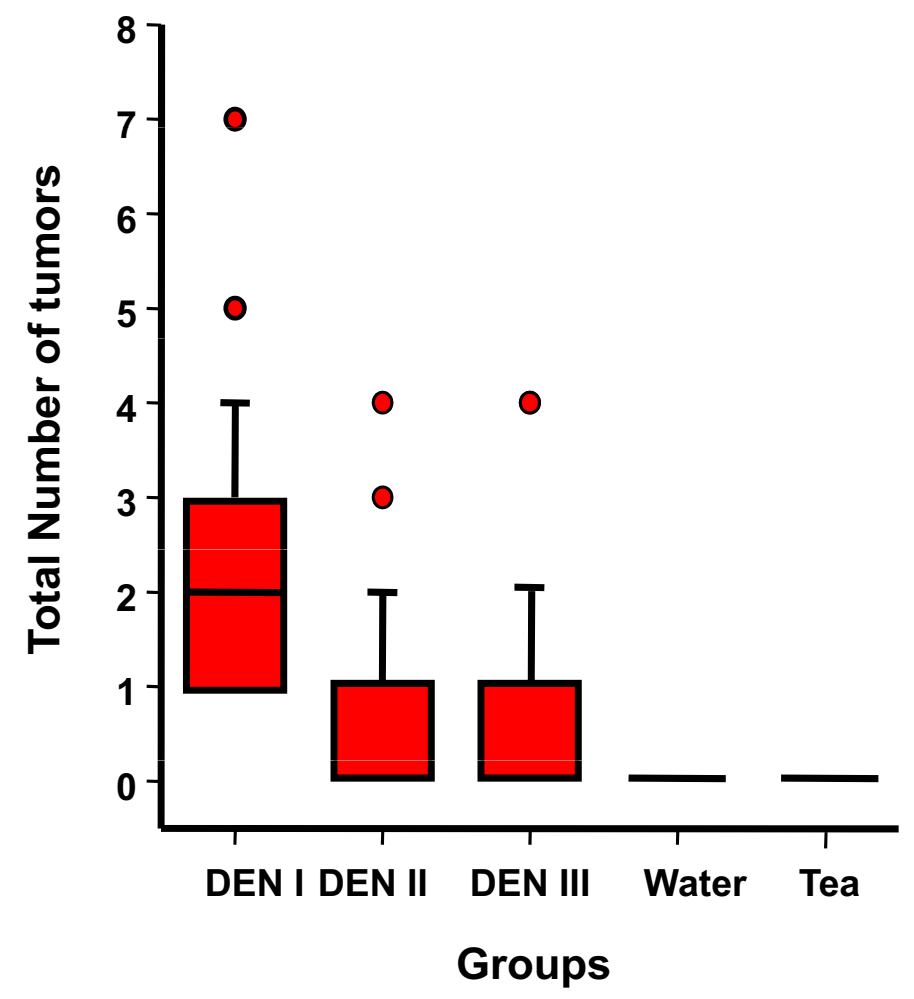

FIGURE 1 - Tumor frequency at the macroscopic examination

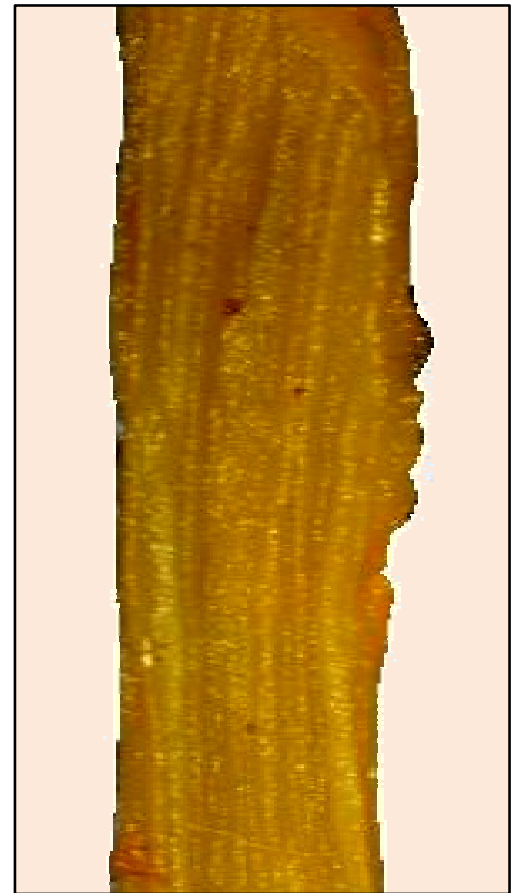

FIGURE 2 - Normal specimen from animal of group Water (10x)

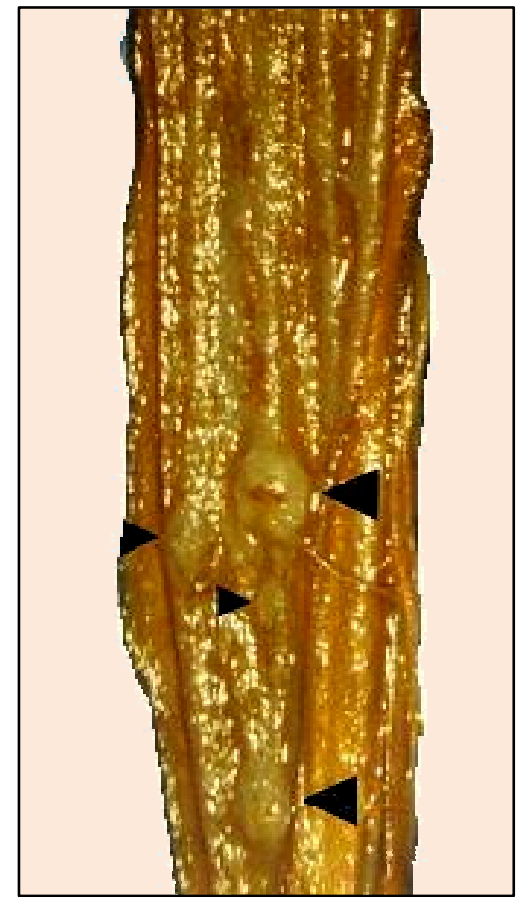

FIGURE 3 - Esophagus of a specimen of group DEN I, with tumors at the distal third $(25 \mathrm{x})$

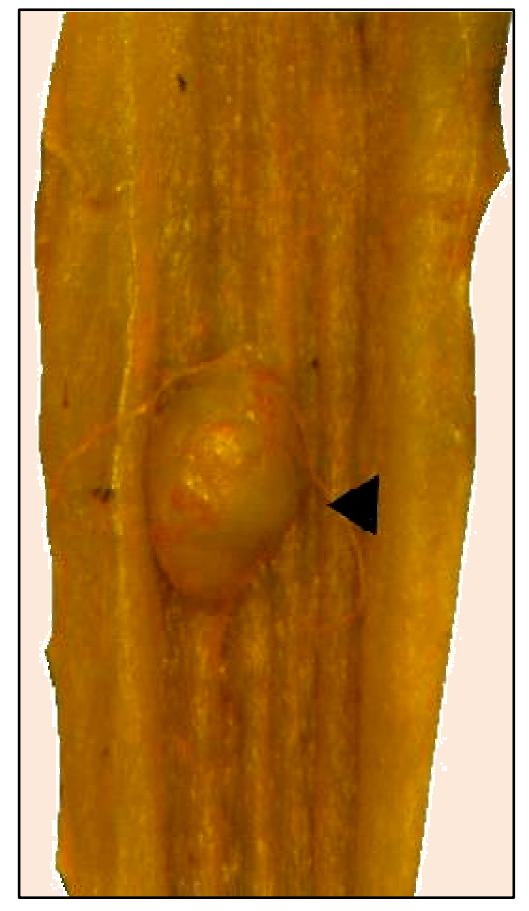

FIGURE 4 - Excrescent tumor in the esophagus of a specimen of group DEN II (40x) 
Microscopy

Differently from groups DEN II and DEN III, group DEN I did not present normal pieces: all had tumors, often more than one. Corresponding histopathologic findings were found in all of them.

There were 6 cases of low grade dysplasia in tissue samples considered macroscopically normal (no tumor) (Figure 5), all of them from groups treated with tea, but there were no macroscopic lesions (tumors) without corresponding microscopic alterations.

The control groups did not show changes in the tissue samples collected randomly, as there was no tumor at macroscopy. Both in the general evaluation of the lesions and the other pieces of esophagus, and in the analysis based on the lesion of highest grade shown by each individual, there was a similarity between groups DEN II and DEN III, treated with tea; nevertheless, there was a significant difference between these and group DEN I, which did not receive tea, regarding the frequency and severity of epithelial lesions (Table 2).

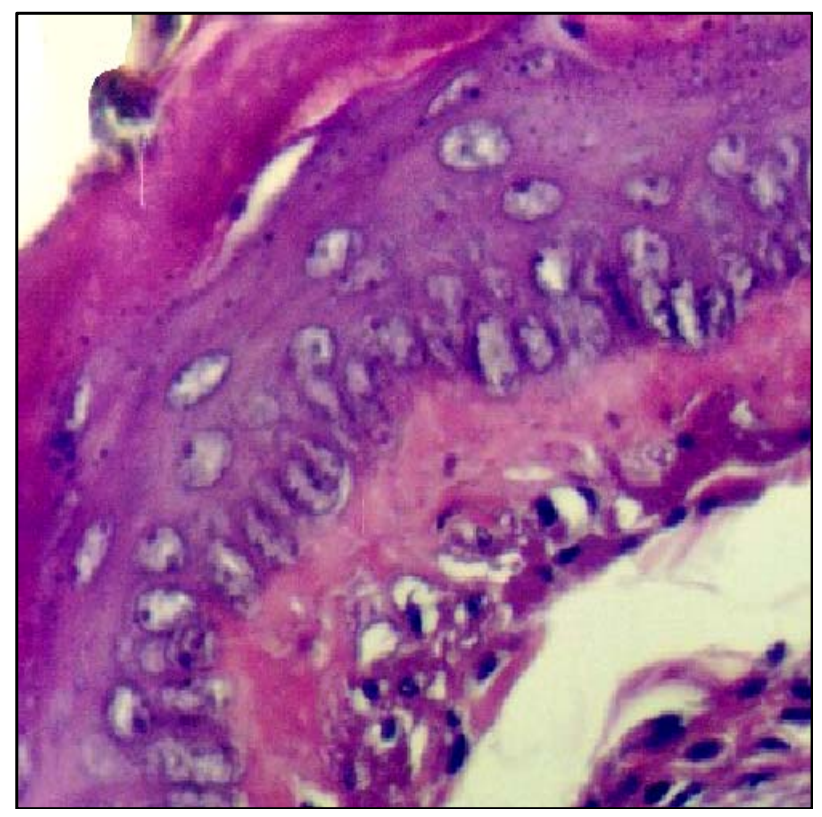

FIGURA 5 - Low grade dysplasia: increased cellularity and frequent mitoses (specimen from group DEN III - 100x)

TABLE 2 - Distribution of findings diagnosed at macroscopy and microscopy

\begin{tabular}{|c|c|c|c|c|c|c|}
\hline \multirow{2}{*}{ Lesions } & \multicolumn{3}{|c|}{ Treatment Groups } & \multicolumn{2}{|c|}{ Control Groups } & \multirow{2}{*}{$\begin{array}{l}\text { Total } \\
\mathrm{n}=177\end{array}$} \\
\hline & $\begin{array}{l}\text { DEN I } \\
n=76\end{array}$ & $\begin{array}{l}\text { DEN II } \\
n=42\end{array}$ & $\begin{array}{l}\text { DEN III } \\
\mathrm{N}=47\end{array}$ & $\begin{array}{c}\text { Water } \\
n=6\end{array}$ & $\begin{array}{c}\text { Tea } \\
n=6\end{array}$ & \\
\hline $\begin{array}{l}\text { 1. Macroscopy } \\
\text { (tumors) }\end{array}$ & 76 & 27 & 36 & 0 & 0 & 139 \\
\hline 2. Histopathology & 76 & 30 & 39 & 0 & 0 & 145 \\
\hline a. normal & 0 & 12 & 08 & 06 & 06 & 32 \\
\hline $\begin{array}{l}\text { b. low grade } \\
\text { dysplasia }\end{array}$ & 48 & 26 & 29 & 0 & 0 & 103 \\
\hline $\begin{array}{l}\text { c. high grade } \\
\text { dysplasia }\end{array}$ & 24 & 04 & 10 & 0 & 0 & 38 \\
\hline $\begin{array}{l}\text { d. invasive } \\
\text { carcinoma }\end{array}$ & 04 & 0 & 0 & 0 & 0 & 04 \\
\hline
\end{tabular}

In the distribution of frequencies the data appear as absolute counts.

In Groups DEN II and DEN III, which presented cell alterations of lesser severity than those of Group DEN I, the lesions were distributed in similar fashion as regards the degree of epithelial injury. There was a strong correlation between higher frequency of tumors at macroscopy and greater histopathologic severity of lesions, features present in Group DEN I, as compared to groups that received black tea (DEN II and
DEN III) (Figures 6 and 7). Group DEN I presented lesions with greater epithelial impairment. The incidence of invasive carcinoma, though small, was unique to Group DEN I. These findings, analyzed by one way ANOVA applied over Ranks, indicated three ranges of difference concerning the severity of lesions: groups Water and Tea; groups DEN II and DEN III; group DEN I (Figure 8 and Table 3 ). 


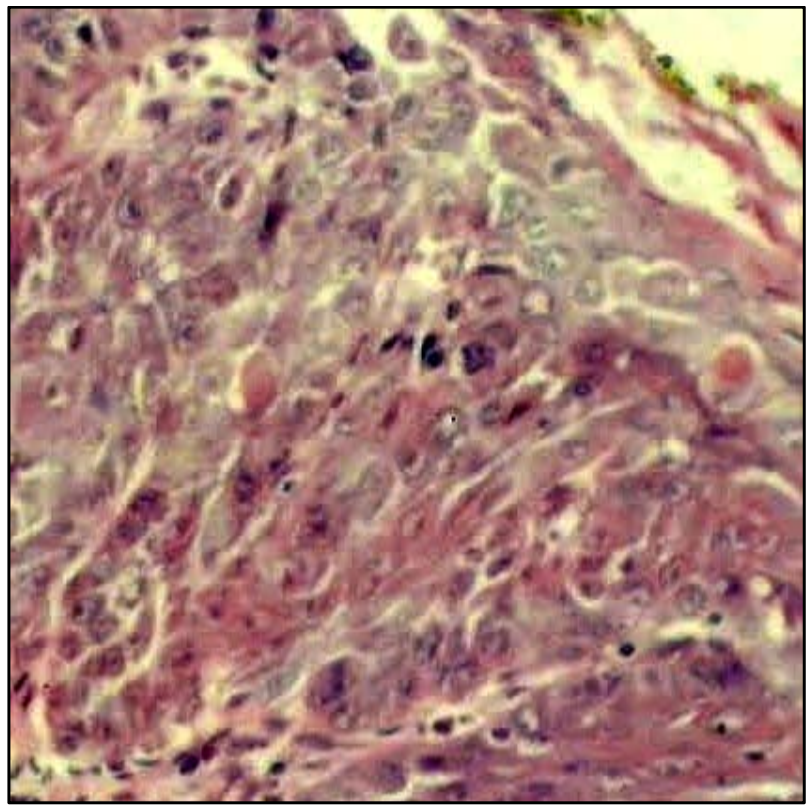

FIGURE 6 - High grade dysplasia: pavement cells throughout the epithelium and intense nuclear atypia (specimen from group DEN I - 200x)

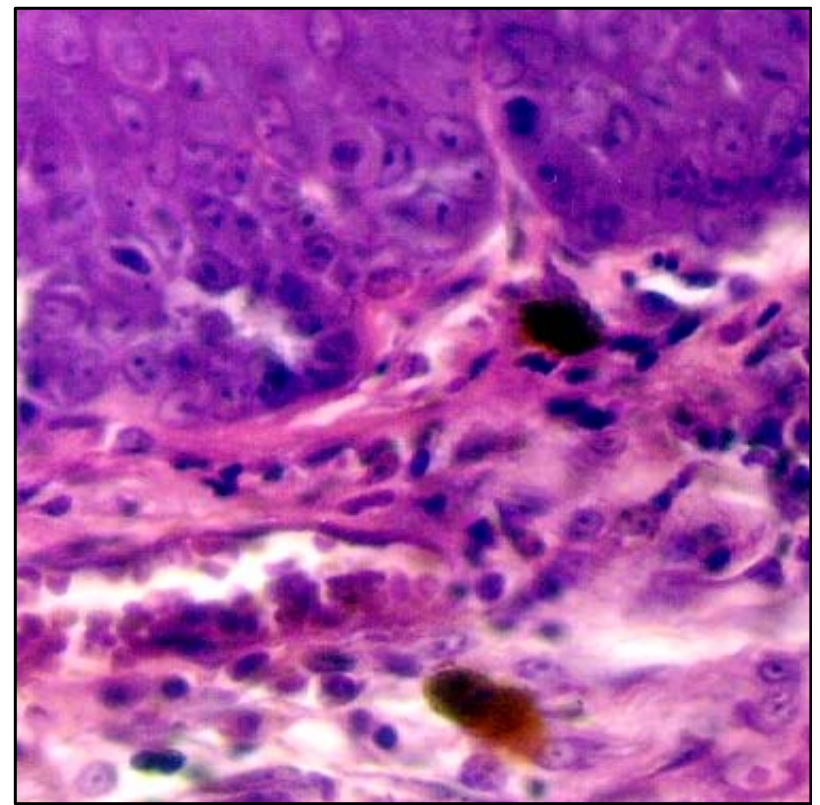

FIGURE 7 - Invasive carcinoma: intense nuclear atypia and epithelial cells beyond the basal lamina (specimen of group DEN I - 250x)

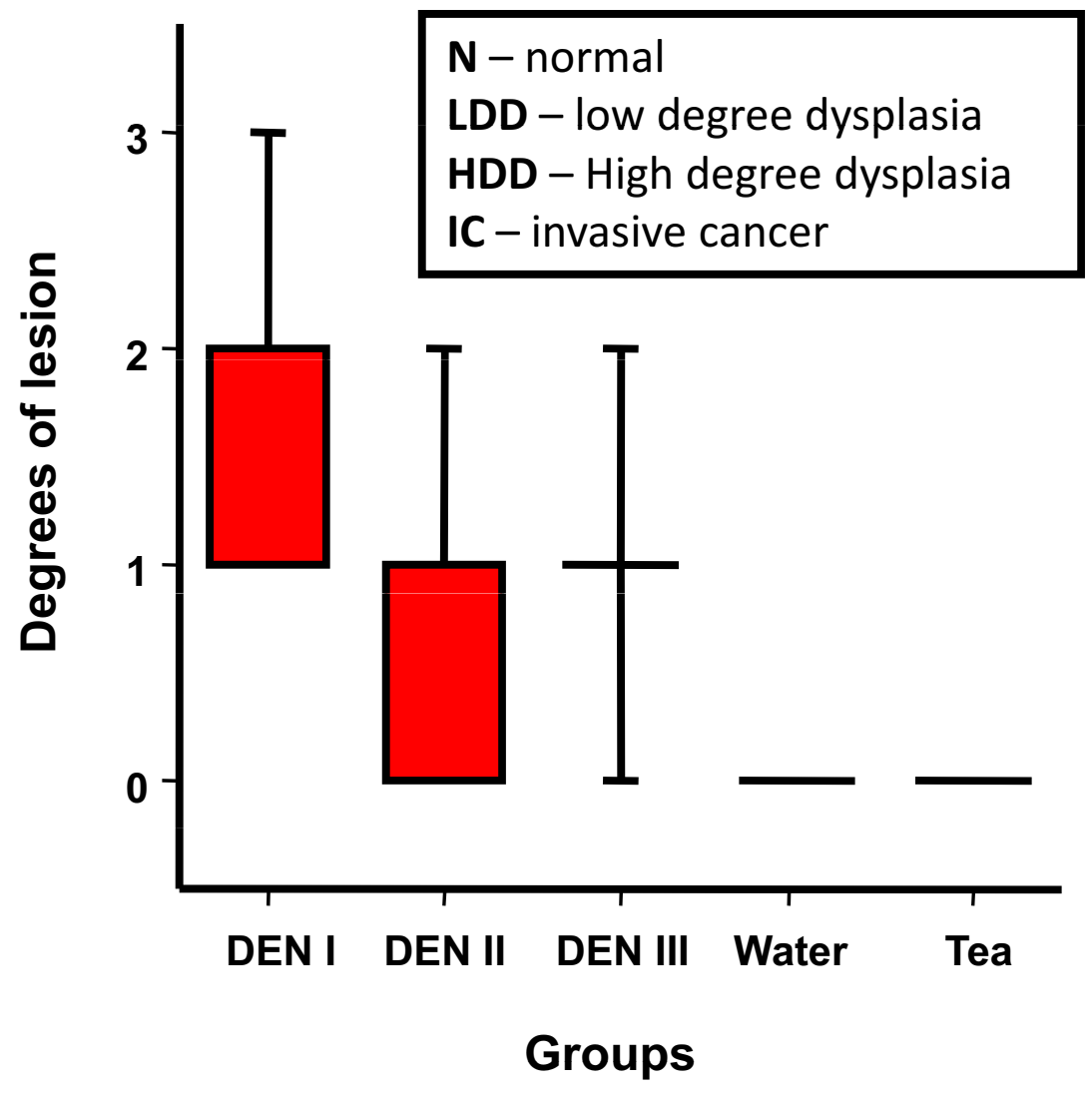

FIGURE 8 - Distribution of lesions according to intensity 
TABLE 3 - Histopathologic analysis considering the most severe lesion of each specimen

\begin{tabular}{|c|c|c|c|c|c|}
\hline \multirow{2}{*}{ Lesions } & \multicolumn{3}{|c|}{ Treatment Groups } & \multicolumn{2}{|c|}{ Control Groups } \\
\hline & $\begin{array}{l}\text { DEN I } \\
n=34\end{array}$ & $\begin{array}{l}\text { DEN II } \\
n=34\end{array}$ & $\begin{array}{l}\text { DEN III } \\
n=34\end{array}$ & $\begin{array}{l}\text { Water } \\
n=6\end{array}$ & $\begin{array}{c}\text { Tea } \\
n=6\end{array}$ \\
\hline Normal & 0 & 12 & 08 & 06 & 06 \\
\hline $\begin{array}{l}\text { Low Grade } \\
\text { Dysplasia }\end{array}$ & 11 & 18 & 20 & 0 & 0 \\
\hline $\begin{array}{l}\text { High Grade } \\
\text { Dysplasia }\end{array}$ & 19 & 04 & 06 & 0 & 0 \\
\hline $\begin{array}{l}\text { Invasive } \\
\text { Carcinoma }\end{array}$ & 04 & 0 & 0 & 0 & 0 \\
\hline Median & $2.0^{\mathrm{a}}$ & $1.0^{\mathrm{b}}$ & $1.0^{\mathrm{b}}$ & $0.0^{c}$ & $0.0^{c}$ \\
\hline $\begin{array}{l}\text { Minimum and } \\
\text { Maximum }\end{array}$ & $1-3$ & $0-2$ & $0-2$ & $0-0$ & $0-0$ \\
\hline
\end{tabular}

In the distribution of frequencies, the data appear as absolute counts.

Comparison of groups by oneway ANOVA over Ranks, $\mathrm{p}<0.001$.

The index letters represent differences at the DUNCAN post-hoc test $(a \neq b ; b \neq c ; a \neq c)$.

\section{Discussion}

Other animals susceptible to tumor induction can be used for studying esophageal carcinogenesis, but these imply greater operational costs. In the present work, Mus musculus CF1 mice were used because they are suitable to the proposed study and costs were minimized ${ }^{22}$. We have chosen to use only females in order to avoid the frequent deaths resulting from conflicts of territoriality, typical of males ${ }^{24}$, which could compromise the investigation, as other less controllable losses are typical to this experimental model.

The experiment was designed to last 160 days based on the principles of experimental chemical carcinogenesis and the tumor size established $(1 \mathrm{~mm})$, since the emergence of an invasive carcinoma occurs after 120 days of DEN consumption ${ }^{23}$. This criterion of macroscopic analysis proved effective in evaluating carcinogenesis, as the tumors $\geq 1 \mathrm{~mm}$ presented correlation with histopathologic changes in the microscopic analysis.

The weight progress of the animals, from similar initial measures $(p=0.617)$, became negative in group DEN I $(p<$ 0.0001), which lacked the attenuating effect of black tea against carcinogenesis. This seemingly logical finding is not the rule in other similar studies, where chemoprophylaxis does not inhibit weight loss.

The concentration of DEN used to induce carcinogenesis $(0,04 \mathrm{ml} / \mathrm{L})$ was the one recommended in other experiments ${ }^{22}$. The oral route is effective and minimizes the handling of animals, besides reducing hepatotoxicity and the debilitating occurrence of tumors in other organs. The concentration of black tea was set as $1 \%$ because this is close to the one of human consumption; there is no established standard for this s $^{25,26,27}$.

The way of administering the black tea, mixed with the carcinogen (group DEN II) or alternated with it (group DEN III), did not have an influence in this study, as the effects were similar. This fact, that DEN mixed to the black tea produces the same effect as when it is administered in alternation with tea, leads one to believe that there was no inhibition of the anticarcinogenic effect of the tea when it is mixed in DEN, in vitro. Studies of the different effects of the tea as regards the way of administering the substance ${ }^{25,28}$ are scanty and unclear. Reports on the use of mixed tea and DEN were not found in the literature.

The treatment groups that drank black tea presented less tumors than Group DEN I ( $p<0.0001)$, the only one presenting tumors across all specimens examined. The mechanisms involved in this result merit further studies for elucidation, but the available evidence allows to conclude that the smaller incidence of tumors observed in Groups DEN II and DEN III ( $p<$ 0.0001 ) is connected with black tea.

Here we did not use the traditional Swiss roll technique for microscopy, but the perpendicular section of lesions identified at macroscopy, which permitted to exclude other lesions from the analysis and a safe confrontation of macroscopy and microscopy, as well as a careful analysis of each tumor.

Dysplasia, considered as the main precursor of epidermoid carcinoma of the esophagus and the commonest pathologic finding in at-risk populations ${ }^{29}$, was the parameter used in the histopathologic study for group comparison. For greater reliability of the analysis, a strict criterion was previously set for the histological rating of lesions, based on cellularity in relation to epithelial surface and basal layer, intensity and extension of the damage to cell structure, presence of mitoses and nuclear atypias, and chromatin characteristics at staining.

At the completion of the study, tumor incidence was significantly smaller in the groups treated with black tea than in group DEN I. The histopathologic analysis revealed a significantly higher incidence of normal esophagi and a lower incidence of severe dysplastic lesions and invasive carcinoma in 
Groups DEN II and DEN III than in group DEN I. The total correspondence between microscopic and macroscopic findings allows to consider that the presence of tumors $\geq 1 \mathrm{~mm}$ at macroscopy was an affirmative element of chemical carcinogenesis in this experimental model. The similarity between the groups treated with black tea, in regard to both tumor incidence and distribution of lesions at histopathology, indicates that there was no previous chemical neutralization of diethylnitrosamine owing to its dilution in black tea (group DEN II).

\section{Conclusion}

In this study, black tea presented a significant anticarcinogenic effect, in similar fashion to a true chemoprophylactic agent, attenuating the process of esophageal carcinogenesis induced by diethylnitrosamine, both when administered separately and when administered in solution with the carcinogen.

\section{References}

1. Ghadirian P. Familial history of esophageal cancer. Cancer. 1985;56:2112-6.

2. Ghadirian P. Thermal irritation and esophageal cancer in Northern Iran. Cancer. 1987;60:1909-14.

3. Opitz OG, Harada H, Suliman Y. Rhoades B, Sharpless NE, Kent R, Kopelovich L, Nakagawa H, Rustgi AK. A mouse model of human oral-esophageal cancer. J Clin Invest. 2002;110:761-9.

4. Weinberg RA. Tumor suppressor genes. Science. 1991;254:1138-46.

5. Guo WD, Li JY, Blot WJ, Hsing AW, Chen J, Fraumeni JF Jr. Correlations of dietary intake and blood nutrient levels with esophageal cancer mortality in China. Nutr Cancer. 1990;13:121-7.

6. Russo A, Franceschi S. The epidemiology of esophageal cancer. Ann Ist Super Sanita. 1996;32:65-72.

7. Dhar GM, Shah GN, Naheed B, Hafiza. Epidemiological trend in the distribution of cancer in Kashmir Valley. J Epidemiol Community Health. 1993;47:290-2.

8. Mahboubi E. Epidemiologic study of esophageal carcinoma in Iran. Int Surg. 1971;56:68-71.

9. Farber E. Cancer development and its natural history: a cancer prevention perspective. Cancer. 1988;62:1676-9.

10. Han J. Highlights of the cancer chemoprevention studies in China. Prev Med. 1993;22:712-22.

11. Hecht SS. Approaches to cancer prevention based on an understanding of N-nitrosamine carcinogenesis. Proc Soc Exp Biol Med.
1997;216:181-91.

12. Stoner GD, Gupta A. Etiology and chemoprevention of esophageal squamous cell carcinoma. Carcinogenesis. 2001;22:1737-46.

13. Weisburger JH. Practical approaches to chemoprevention of cancer. Drug Metab Ver. 1994;26:253-60.

14. Stavric B. Role of chemopreventers in human diet. Clin Biochem. 1994;27:319-32.

15. Gao YT, McLaughlin JK, Blot WJ, Ji BT, Dai Q, Fraumeni JF Jr. Reduced risk of esophageal cancer associated with green tea consumption. J Natl Cancer Inst. 1994;86:855-8.

16. Komori A, Yatsunami J, Okabe S, Abe S, Hara K, Suganuma M, Kim SJ, Fujiki H. Anticarcinogenic activity of green tea polyphenols. Jpn J Clin Oncol. 1993;23:186-90.

17. Mukhtar H, Wang ZY, Katiyar SK, Agarwal R. Tea components: antimutagenic and anticarcinogenic effects. Prev Med. 1992;21:351-60. 18. Shiraki M, Hara Y, Osawa T, Kumon H, Nakayama T, Kawakishi S. Antioxidative and antimutagenic effects of theaflavins from black tea. Mutat Res. 1994;323:29-34.

19. Katiyar SK, Mukhtar H. Tea antioxidants in cancer chemoprevention. J Cell Biochem. 1997;27:59-67.

20. Weisburger JH, Hara Y, Dolan L, Luo FQ, Pittman B, Zang E. Tea polyphenols as inhibitors of mutagenicity of major classes of carcinogens. Mutat Res. 1996;37:57-63.

21. Serafini M, Ghiselli A, Ferro-Luzzi A. In vivo antioxidant effect of green and black tea in man. Eur J Clin Nutr. 1996;50:28-32.

22. Rubio CA, Liu F, Chejfec G, Sveander M. The induction of esophageal tumors in mice: dose and time dependency. In Vivo. 1987;1:35-8.

23. Rubio CA. Post-carcinogen interval in carcinogenesis. Eur J Cancer Clin Oncol. 1988;24:499-500.

24. Kruel CDP, Gurski RR, Golbert L, Luz L, Ferreira M, Lemos N. Effect of thermal injury and the oral administration of diethylnitrosamine in the development of esophageal tumors in mice. In: Perachia, A. Recent advances in diseases of the esophagus. Bolonha: Monduzzi; 1996. p 37-40.

25. Wang $\mathrm{H}, \mathrm{Wu}$ Y. Inhibitory effect of chinese tea on N-Nitrosation in vitro and in vivo. IARC Sci Publ. 1991;105:546-9.

26. Wang ZY, Wang LD, Lee MJ, Ho CT, Huang MT, Conney AH, Yang CS. Inhibition of N-nitrosomethylbenzylamine-induced esophageal tumorigenesis in rats by green and black tea. Carcinogenesis. 1995;16:2143-8.

27. Yang CS, Chen L, Lee MJ, Landau JM. Effects of tea on carcinogenesis in animal models and humans. Adv Exp Med Biol.1996;401:51-61. 28. Wu YN, Wang HZ, Li JS, Han C. The inhibitory effect of Chinese tea and its polyphenols on in vitro and in vivo N-nitrosation. Biomed. Environ Sci. 1993;6:237-58.

29. Dry SM, Lewin KJ. Esophageal squamous dysplasia. Semin. Diagn. Pathol. 2002;19:02-11.

\section{Correspondence:}

Átila Velho

Rua Prof. Ivo Corseuil, 324/401

90690-410 Porto Alegre - RS Brazil

Phone: (55 51)3383-0573 / 99820212

atila.velho@,terra.com.br
Conflict of interest: none Financial source: none

Received: January 16, 2008

Review: February 15, 2008

Accepted: March 20, 2008

\section{How to cite this article}

Velho AV, Hartmann AA, Kruel CDP. Effect of black tea in diethylnitrosamine-induced esophageal carcinogenesis in mice. Acta Cir Bras. [serial on the Internet] 2008 July-Aug;23(4). Available from URL: http://www.scielo.br/acb

*Color figures available from www.scielo.br/acb 